\title{
Foraminifera in Late Saalian, Eemian, Early and Middle Weichselian of the Skærumhede I boring
}

\author{
KAREN LUISE KNUDSEN AND ANNE-LISE LYKKE-ANDERSEN
}

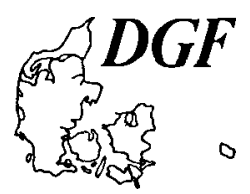

Knudsen, K. L. and Lykke-Andersen, A.-L.: Foraminifera in Late Saalian, Eemian, Early and Middle Weichselian of the Skærumhede I boring. Bull. geol. Soc. Denmark, vol. 30, pp. 97-109, Copenhagen, September 1st, 1982. https://doi.org/10.37570/bgsd-1981-30-10

\begin{abstract}
A foraminiferal stratigraphy primarily based on the late Axel Nørvangs material from the Skærumhede I boring has been made.

Foraminifera from the marine Skærumhede sequence show a faunal succession from an arctic environment (zone N4) to deep water boreal and boreo-lusitanian conditions (zone N3). This is succeeded by a zone (N2) containing a faunal transition from a shallow water boreal assemblage in its lower part through to boreo-arctic conditions in its upper part, and finally a zone (N1) reflecting mainly arctic environment. It is argued that zone N4 represents the Late Saalian, zone N3 the Eemian and zones N2 and N1 the Early and Middle Weichselian.
\end{abstract}

K. L. Knudsen, Department of Micropaleontology, Institute of Geology, University of Aarhus, 8000 Arhus C, Denmark; A.-L. Lykke-Andersen, Labyrinten 17, 8220 Brabrand, Denmark, 1982. March, 22nd, 1982.

At Skærumhede, about $10 \mathrm{~km}$ west of Frederikshavn in Vendsyssel (fig. 1), three borings have been carried out by the Geological Survey of Denmark.

The Skærumhede I boring was made in 1905. This boring was $235 \mathrm{~m}$ deep and contained a 123 $\mathrm{m}$ thick marine sequence resting on $20 \mathrm{~m}$ of till and fluvioglacial deposits. It was overlain by about $57 \mathrm{~m}$ fluvioglacial deposits (Jessen et al., 1910).

The marine Skærumhede sequence was originally subdivided using molluscs into the Turritella terebra zone, the Abra nitida zone and the Portlandia arctica zone (figs. 2 and 3). Jessen et al. (1910) concluded "The changes in the climatic conditions - from temperate to high arctic - displayed by the molluscan fauna, thus show that these marine formations resting on a primary bed, which are covered by and rest upon glacial formations, were deposited during an Interglacial Period and the beginning of the next following Glacial Period".

Correlation between the Portlandia arctica zone and the Older Yoldia Clay, known from several localities in Vendsyssel, leads to the conclusion that the marine part of the Skærumhede series belongs to the last Interglacial period and the beginning of the last Glacial period. However
Jessen et al. (1910) pointed out that "The fauna in the Eem deposits, which at present are also referred to the last Interglacial Period, has a different and far too southern a character, to be brought into close connection with the Skærumhede series".

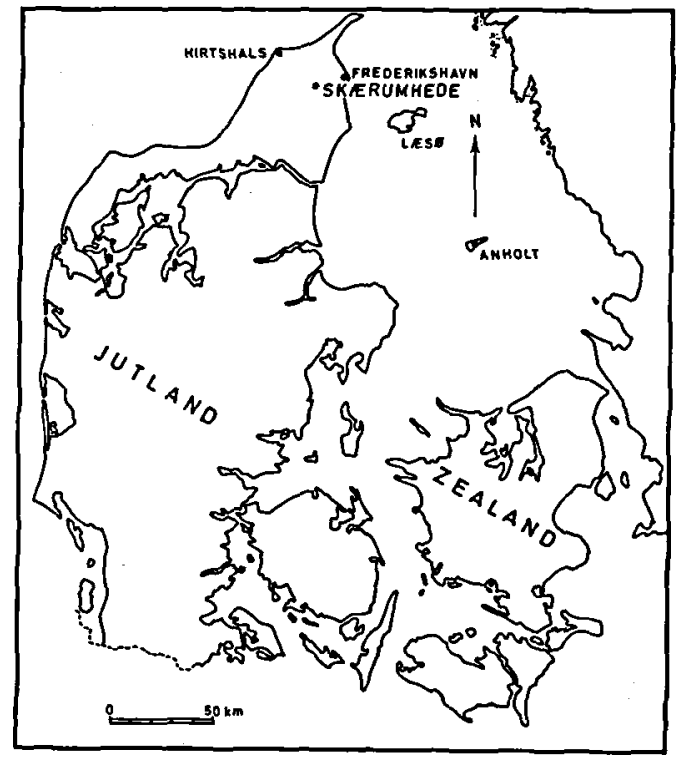

Fig. 1. Locality map. 
The fact that the molluscan fauna from the temperate part of the Skærumhede series is different from that known from shallow water Eemian deposits has been the argument used by several authors to refer the marine Skærumhede sequence to different interglacial, glacial and interstadial periods in the Quaternary stratigraphy (for further discussion see Bahnson et al., 1974).

Comparison between the Older Yoldia clay in Hirtshals coast cliff and the Portlandia arctica zone of the Skærumhede I boring, based mainly upon the sediments and their content of molluscs but also on the foraminifera, shows that the Older Yoldia Clay at Hirtshals corresponds to the upper c. $30 \mathrm{~m}$ of the Portlandia arctica zone together with the lowermost part of the fluvioglacial deposits (Lykke-Andersen, 1971).

Radio carbon dates of plant material and molluscs from the Older Yoldia Clay in Hirtshals coast cliff, gave ages which seem to prove that this deposits and therefore also the upper c. $30 \mathrm{~m}$ of the Portlandia arctica zone have been deposited exclusively in the Middle Weichselian (Lykke-Andersen, 1981, 1982 and fig. 5, this paper).

The second boring at Skærumhede was made in 1971-72. It was $122 \mathrm{~m}$ deep and located only a few metres from the Skærumhede I boring. This boring contained only the upper part of the marine Skærumhede sequence, i.e. the Portlandia arctica zone, the Abra nitida zone and the uppermost part of the Turritella terebra zone (see fig. 5).

A detailed foraminiferal zonation of the marine sequence in Skærumhede II was made by Konradi and Knudsen (1974). As this boring only contains the upper part of the marine sequence, it is obvious that the foraminiferal material from Skærumhede I provides important additional information from earlier in the stratigraphy. A rough outline of the foraminiferal stratigraphy combining the Skærumhede I and Skærumhede II borings was published in 1980 by Feyling-Hanssen and Knudsen.

The Skærumhede III boring from 1974 was only $34 \mathrm{~m}$ deep and did not reach the marine sequence (Bahnson et al., 1974).

Recent workers have again considered that the marine sequence at Skærumhede represents the Late Saalian, Eemian and Early and Middle Weichselian (Feyling-Hanssen et al., 1971; Bahnson et al., 1974; Knudsen, 1976; FeylingHanssen and Knudsen, 1980; Lykke-Andersen, 1981). For additional discussion of the stratigraphic position, the reader is referred to these authors.

\section{Material and methods}

Foraminifera from the Skærumhede I boring were studied by the late Axel Nørvang. He delivered a lecture about his results in the Geological Society of Denmark (Nørvang, 1945) but he never published the foraminiferal stratigraphy.

This paper is an attempt to publish Nørvangs results using his remaining material, viz. some sample residues, "faunal" slides, index cards and a fragmentary manuscript.

The sample material, which was at Nørvangs disposal for foraminiferal analyses consisted of casings stored for many years.

Nørvang did not analyse the faunal compositions by counting, but by use of a five level scale of relative frequency (abundant, common, scarce, rare, fragments). By comparing the estimates, made by Nørvang, with his "faunal" slides, and with faunas known from the Skærumhede II boring, it would appear that more weight was given to the larger species than actual frequencies by counting would have demonstrated. One reason for underrepresentation of smaller specimens may be the special preparation method used by Axel Nørvang, but as some of the "faunal" slides also contain many small specimens, it may partly be caused by deliberate selection of the foraminifera. Examination of Nørvangs sample remains from no. 139 and especially no. 109 show that many small specimens were left behind after preparation. To obtain a better knowledge of the complete faunas, we have processed 19 selected samples from the original Skærumhede I material. These samples were processed according to the methods described by Feyling-Hanssen et al. (1971).

Fig. 2. Relative frequencies of selected species of foraminifera in the lower part of the Skarumhede sequence, based on Nørvangs results (legend fig. 4). 


\section{SKERUMHEDE I}

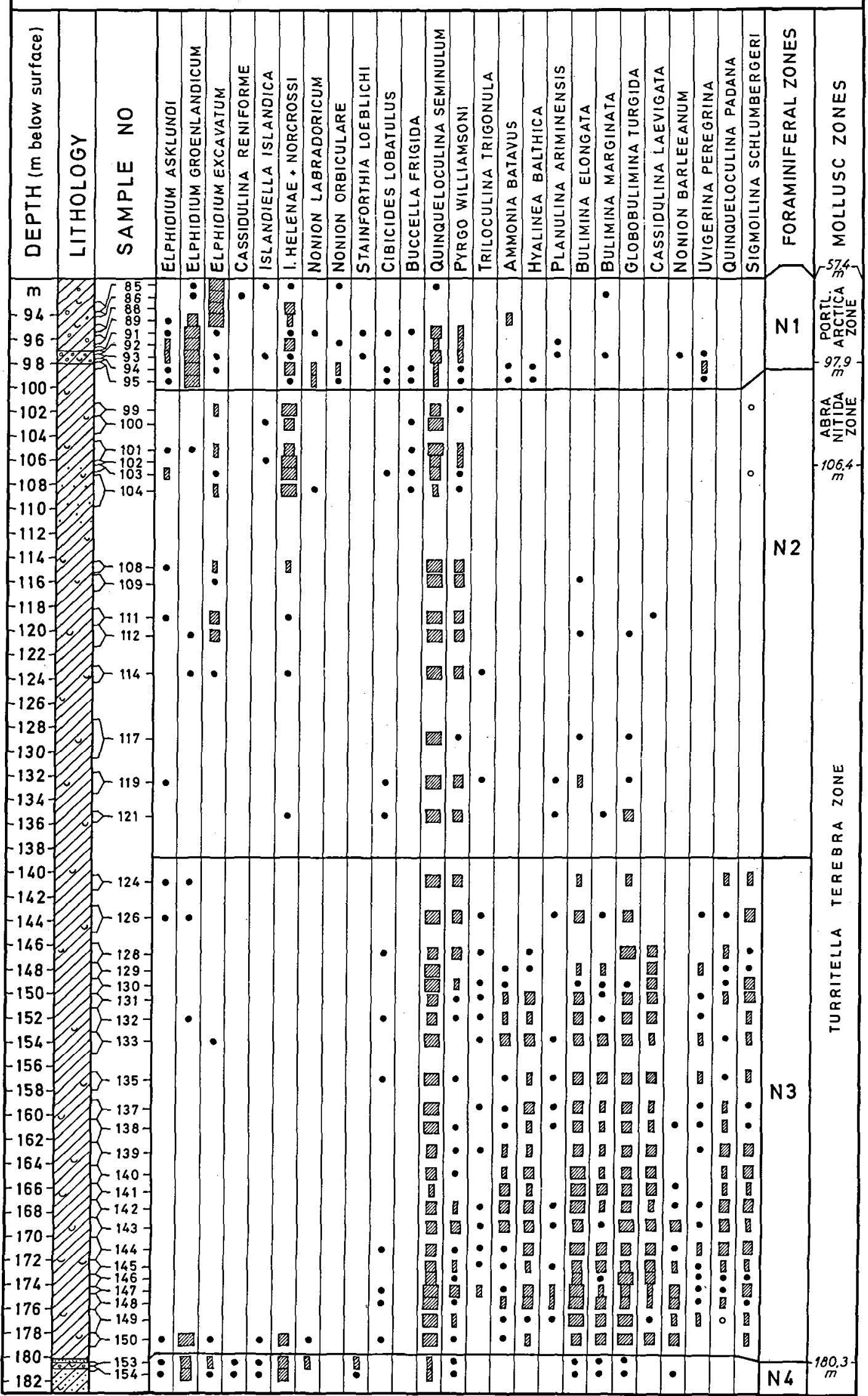


Using the available information extracted from Nørvangs papers, figure 2 has been constructed showing relative frequencies of the most common species of foraminifera. Species names have been altered according to the modern day usage, and taxonomic problems have been solved by careful examination of the foraminiferal material, which was collected by Nørvang.

The upper part of the Skærumhede I boring, above $93 \mathrm{~m}$ depth, has been left out of this range chart (fig. 2), partly because the faunal information there was very fragmentary, but also because a foraminiferal zonation of this section of the boring has been constructed using much better material from Skærumhede II (fig. 5). The lower part of Skærumhede I (93-181 m below ground level) produced reasonably representative faunal distributions, which are shown here in fig. 2 based exclusively on Nørvangs results.

Results of our supplementary foraminiferal investigations of the original Skærumhede I material are shown in fig. 3 . Seven additional species are added to the right of the diagram. Peter Konradi, Geological Survey of Denmark, kindly placed some of his faunal lists from Skærumhede I at our disposal, and his results (samples 89, 97, $101,104,150,152$ and 157) are entered in the range chart together with ours (fig. 3 ).

The foraminiferal "zones" in the present work are assemblage zones, according to the definition given by Hedberg (1976), but the term "zone" is used for the purpose of brevity.

\section{Foraminiferal zonation}

The marine sequense of the Skærumhede I boring was subdivided into four assemblage zones by Nørvang, here called N1, N2, N3 and N4.

The lowermost zone, N4, which was included in the "lower glacial beds" by Nørvang, is in his material represented by only two samples (154 and 153) from $181.1 \mathrm{~m}$ to $180.5 \mathrm{~m}$ depth. The most common species in zone $\mathrm{N} 4$ are Elphidium groenlandicum, E. excavatum, Islandiella helenae (including $I$. norcrossi), Nonion labradoricum, Stainforthia loeblichi and Quinqueloculina seminulum (fig. 2). This composition of species together with the occurrence of Cassidulina reniforme show, that the zone represents an arctic marine environment. The presence of a small number of boreal species, which are dominant in the zone above, was probably caused by contamination during sampling.

Additional samples selected from the "lower glacial beds" (199.3-180.3 m) have been analysed for foraminiferal content (fig. 3). The lowermost sample 192 (199.3-199.1 m), which consisted of coarse clayey sand and gravel, contained a rich foraminiferal fauna indicating an arctic environment. Elphidium excavatum, Cassidulina reniforme and Islandiella helenae dominate the assemblage and Elphidium groenlandicum, Nonion labradoricum and Stainforthia loeblichi are the most common accessory species (fig. 3). In spite of the fact that this marine deposit rests directly on top of the White Chalk, the content of Prequaternary foraminifera is extremely low.

Above this marine sand and gravel follows a $14.3 \mathrm{~m}$ thick deposit of clayey till. Five samples from this sequence have been analysed. These sediments were found to contain extremely large quantities of Prequaternary foraminifera (10007000 specimens per $100 \mathrm{~g}$ sediment), Quaternary species were however low in number (fig. 3).

The till is overlain by $0.8 \mathrm{~m}$ of coarse gravel followed by sand with clay layers and sandy clay containing pebbles and mollusc shells (183.4$180.5 \mathrm{~m}$ ). Samples from this deposit contain rich Quaternary foraminiferal faunas, but in contrast to sample 192 from the lowermost part of the marine sequence, there is also a rather high content of Prequaternary specimens (from 10 to $50 \%$ of the Quaternary content). The Quaternary faunal composition in samples $154,155,157$ and 158 is very similar to that described from the lowermost sample, except that $E$. groenlandicum is less frequent in this upper part (fig. 3). A thin layer of coarse sand $(180.5-180.3 \mathrm{~m})$ representing the uppermost part of the "lower glacial beds" contains only very few Quaternary as well as Prequaternary foraminifera (sample 152, fig. 3).

The present foraminiferal analysis shows that zone N4 includes two marine transgressions in an arctic environment, separated by a glacial advance.

Zone N3, the Quinqueloculina padana zone, is about $40 \mathrm{~m}$ thick (179-139 $\mathrm{m}$ below surface). In this zone boreal and boreo-lusitanian species are 


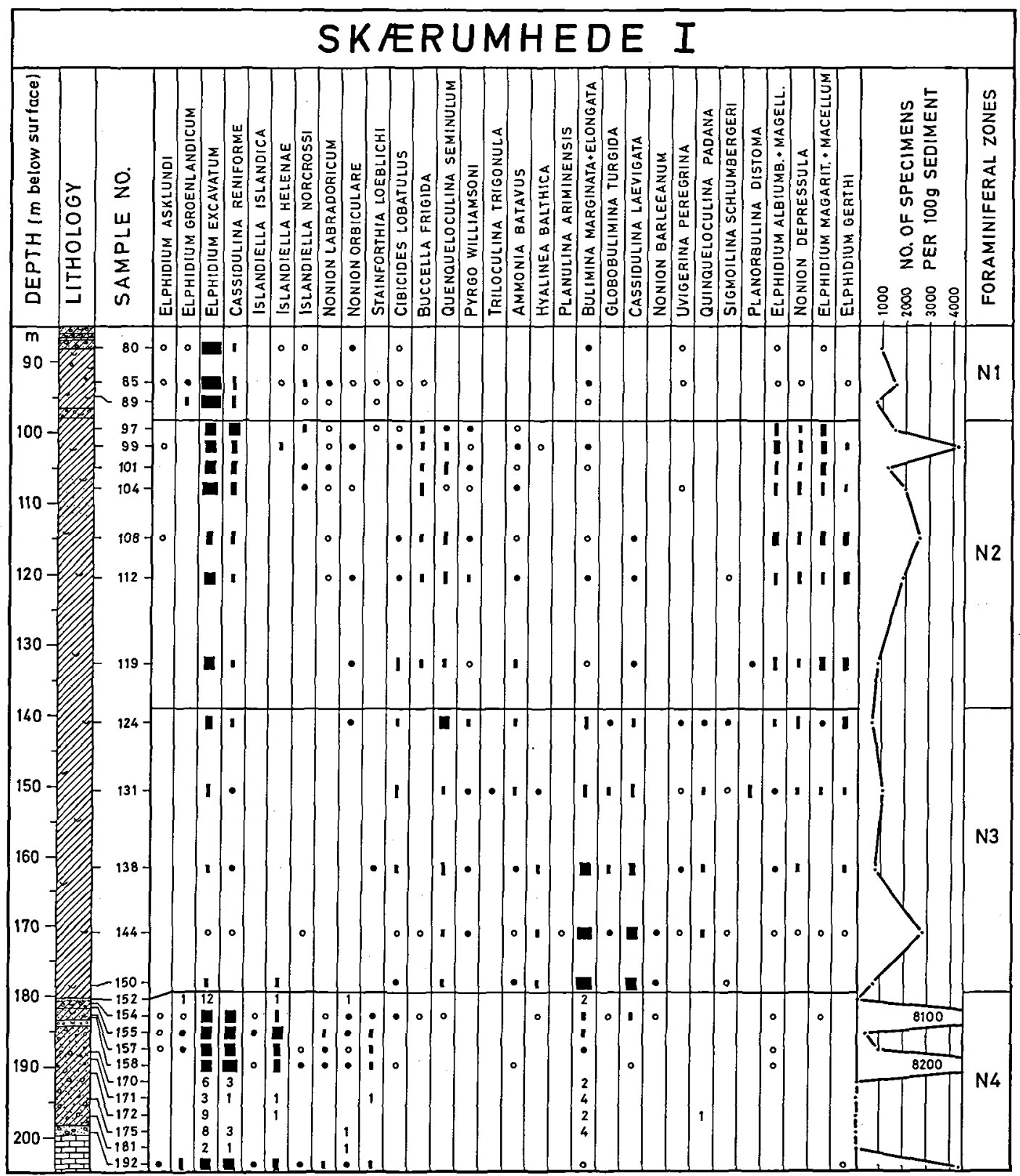

Fig. 3. Percentage distribution of selected foraminiferal species in some of the original samples from Skærumhede I (legend fig. 4).

dominant, i.e. Quinqueloculina seminulum, Ammonia batavus, Hyalinea balthica, Bulimina elongata, B. marginata, Globobulimina turgida, Cassidulina laevigata, Quinqueloculina padana and Sigmoilina schlumbergeri. Planulina ariminensis and Uvigerina peregrina also occur in many of the samples, but Nonion barleeanum is only common in the lowermost part of zone N3 (fig. 2). Investigation of the residues of Nørvangs original material from sample 139 reveals a similar composition of species as his "faunal" slide, and it is noticeable that neither Elphidium excavatum nor other species of Elphidium are present in the remaining part of this sample. Such species are, 


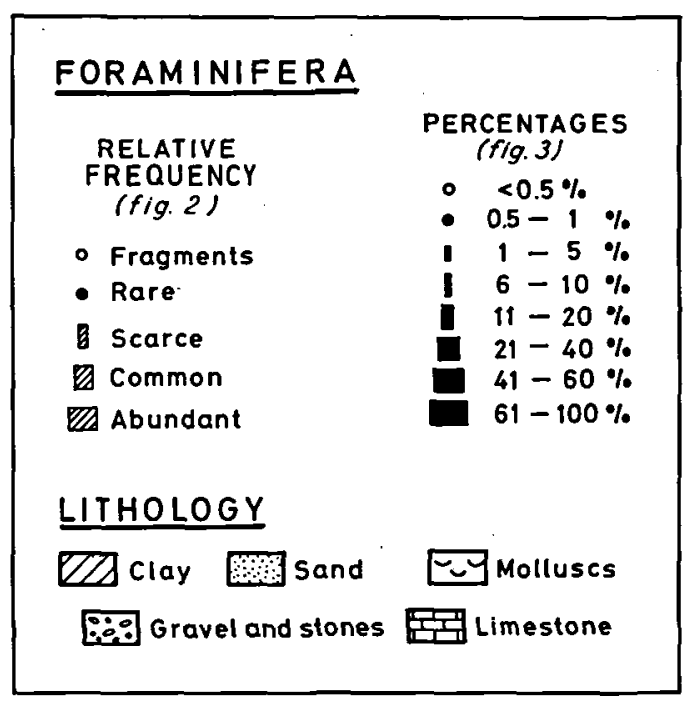

Fig. 4. Legend for the range charts, figs. 2 and 3.

however, found as single specimens within the zone. This is illustrated in our examination of the material (fig.3), which shows increasing percentages of different species of Elphidium in the upper part of zone N3.

The faunal composition of zone N3 indicates marine climatic conditions at least as warm as to-day, but probably slightly warmer. Quinqueloculina padana, which is a characteristic species in this zone, was described from the Upper Pliocene of the Mediterranean (Perconig, 1954) and recorded by several authors from Pliocene, Pleistocene and Recent deposits of this area (Longinelli, 1956; Cita and Chierici, 1962; Lentini, 1968). The recent depth distribution of $Q$. padana is given by Cita and Chierici (1962), who recorded it from $32 \mathrm{~m}$ depth to the deepest sample at $835 \mathrm{~m}$ in the Adriatic Sea, and by Giunta (1954), who recorded it (as $Q$. pentagona, n.sp.) from depths between $75 \mathrm{~m}$ and $125 \mathrm{~m}$ near Genova. Material from $100 \mathrm{~m}$ water depth in the Mediterranean collected by Nørvang, 1962 also contained specimens of $Q$. padana, and in Nørvangs unpublished manuscript of the foraminiferal stratigraphy in Skærumhede I, he actually found that this lusitanian species (described as Miliolinella interglacialis n.sp.) was a characterizing faunal element in the assemblages between $139 \mathrm{~m}$ and $179 \mathrm{~m}$ below ground level, and he named this interval the $\gg$ Miliolinella interglacialis « zone (see also p. 107, this paper).
$Q$. padana has not been found in recent faunas described from the Oslofjord (Risdal, 1964) or from the Gullmar Fjord and the Skagerrak (Höglund, 1947), and it did not occur in recent faunas from 26-80 $\mathrm{m}$ water depth in the Kattegat eihter. (Samples from the area around Læsø were placed at our disposal by Hans Jørgen Hansen, University of Copenhagen). Based on these occurrences $Q$. padana seems to occur exclusively in lusitanian environment.

By comparison with recent faunas the water depth of the zone $\mathrm{N} 3$ assemblages is estimated to be up to 60 to $100 \mathrm{~m}$, probably deeper in the lower part of the zone than in the upper, because of the content of Nonion barleeanum.

The faunas in the upper part of zone N3 are also comparable to Holocene faunas from deposits at about $80 \mathrm{~m}$ water depth in Djupa Rännan off the Swedish west coast (Fält, 1977). The content of Elphidium excavatum in these Holocene faunas together with the very sparce occurrence of Nonion barleeanum indicates a closer correlation with the upper part than with the lower part of zone N3 (fig. 3). Q. padana seems not to occur in Holocene deposits of Djupa Rännan.

Zone N2, the Islandiella helenae-I.norcrossi zone, is about $40 \mathrm{~m}$ thick $(139-98.5 \mathrm{~m})$. The faunal composition varies a great deal through this zone (fig. 2). Quinqueloculina seminulum and Pyrgo williamsoni are common through-out the zone $\mathrm{N} 2$, but Islandiella helenae, I. norcrossi and Elphidium excavatum are only common in its upper part. Here other arctic species also gradually appears.

A comparison of the faunas of zone IX in the Skærumhede II boring with Nørvangs foraminiferal material from the corresponding levels in Skærumhede I demonstrates the underrepresentation of small specimens. This is also shown by an additional examination of samples from zone N2 (fig. 3). Elphidium excavatum is dominant together with the small boreal shallow water species E. albiumbilicatum, E. magellanicum, E. margaritaceum, E. gerthi and Nonion depressula, whilst the content of Cassidulina reniforme (an arctic species) increases in the upper part of the zone.

The faunal composition of zone $\mathrm{N} 2$ shows a transition in marine climatic conditions from a 
boreal environment in the lower part to colder water conditions in the uppermost part of the zone. A subzonation of zone $\mathrm{N} 2$ has not been attempted based on the present material. The upper part of this zone (to $122 \mathrm{~m}$ depth) is represented in the Skærumhede II boring, from which a detailed foraminiferal zonation is described (Konradi and Knudsen, 1974; Knudsen, 1976; see also the correlation below).

Zone N1, the Elphidium asklundi zone, is about $41 \mathrm{~m}$ thick (98.5-57.4 m). Nørvangs material from this zone was very fragmentary, and only the lowermost part of zone $\mathrm{N} 1$ is included in the diagram, fig. 2. Elphidium groenlandicum, Islandiella helenae, I. norcrossi and some miliolids are the most common foraminifera found in Nørvangs material, but a few metres higher in the sequence $E$. excavatum is the dominant species. This assemblage is represented in additional samples, which were analysed from zone N1 (fig. 3).

\section{Correlations and age}

In spite of the rather insufficient foraminiferal material left by Nørvang from the upper part of the Skærumhede I boring, a rudimentary correlation of the foraminiferal zones of the two Skærumhede borings can be made. Of more importance is the fact that the very well preserved faunas from the deeper part of Skærumhede I and the supplementary analysis of original material from this part of the boring provides us with new information from earlier in the stratigraphy.

The arctic zone V of Skærumhede II seems to be correlatable with the Elphidium excavatum dominated part of zone N1 in Skærumhede I, and zones VI and VII are probably represented by the lowermost part of zone $\mathrm{N} 1$ (figs. 2, 3 and 5). The mainly arctic zones in Skærumhede II are included in the Weichselian by Bahnson et al. (1974) (see also Lykke-Andersen, 1981 and 1982).

Zone VIII of Skærumhede II was correlated with the Abra nitida zone by Bahnson et al. (1974). This zone is not distinguishable on the basis of Nørvangs foraminiferal material in Skærumhede I, but additional analyses (fig. 3) shows that this zone VIII is correlatable with the upper part of zone N2 in Skærumhede I.
Zone IX in Skirumhede II, with its characteristic boreal shallow water element, and with a very low content of the arctic Cassidulina reniforme is represented in zone N2 of Skærumhede I, at a level around samples 108-112 (see discussion above). A more detailed correlation of the foraminiferal faunas in zone $\mathrm{N} 2$ with the zonation in the Skærumhede II boring is not possible, but it is obvious that the transition to deeper water faunas in the lower part of zone N2 and especially in zone N3 is not represented in the Skærumhede II boring.

The boreal to boreo-lusitanian faunas of zone N3 in the Skærumhede I boring undouptedly belong to an interglacial period, and according to our opinion it must be the Eemian. Consequently zone N4 represents the Saalian Glacial period. It was not possible, based on the present material to decide, whether there has been a break in marine sedimentation between the glacial and following interglacial period, or if continuous marine sedimentation occurred. In the present area close to the Fennoscandian border zone, local tectonic movements cannot be excluded.

However, corresponding very distinctive faunal changes, from the arctic Weichselian directly into relative deep water boreal faunas of Flandrian age, are also found in borings in the northern North Sea (Feyling-Hanssen, 1980) and in the Kattegatt (Fält, 1977), and this may show a very rapid change in the water masses going from a glacial into an interglacial period. According to Kellogg et al. (1978) and Kellogg (1980) warm Atlantic water penetrated northward into the Norwegian Sea during the Eemian as well as during the Flandrian (see also Sejrup et al., 1980). The rather abrupt faunal change from the arctic zone $\mathrm{N} 4$ to the boreo-lusitanian faunas in zone N3 in Skærumhede I probably reflects a time when the Atlantic water masses could penetrate into the deeper parts of the Norwegian Channel and also into the present Eemian basin. The same was suggested by Fält (1977 and in prep.) at the transition from the Weichselian zone $D$ faunas to the Holocene zone $C$ faunas in borings off the Swedish west coast. On the other hand, a transition zone between Lateglacial and Postglacial assemblages is described in short cores from the Norwegian Channel (Nagy and Ofstad, 1980).

Concerning the boundary between the Eemian 


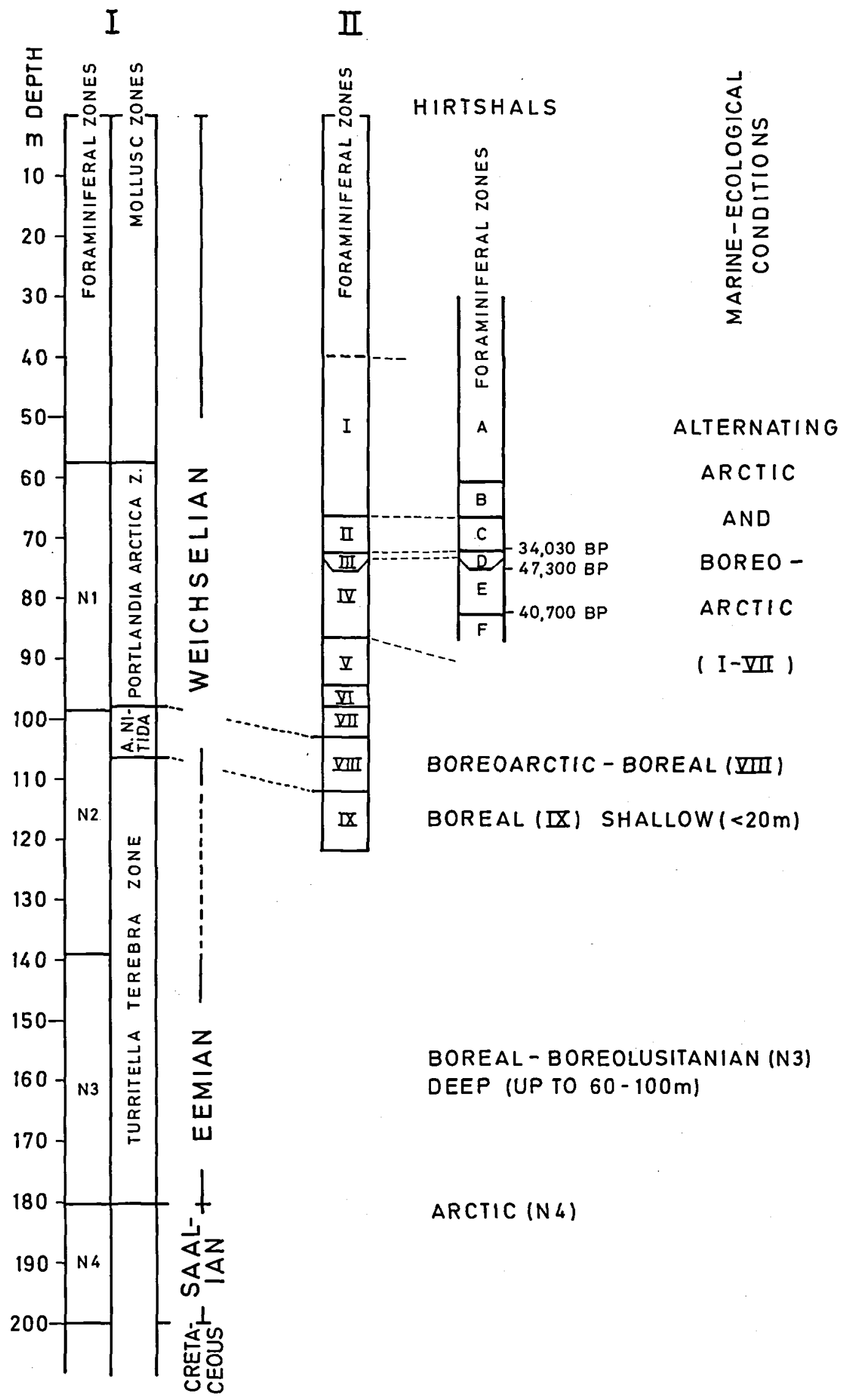


and the Weichselian, Konradi and Knudsen (1974) mentioned that the dominance of boreal and boreo-lusitanian shallow water species in zones IX and VIII in the Skærumhede II boring suggests that these zones should be included in the Interglacial period. This would imply that the top of the Eemian in the Skærumhed I boring is found at the boundary between zones $\mathrm{N} 2$ and N1 (fig. 5).

New radio carbon dates from zones $C$ and $E$ in Hirtshals, which are correlated with zones III and IV in the Skærumhede II boring (fig. 5) suggest a Middle Weichselian age. Mollusc material from zone $C$ gave an age of $34,030 \pm 1310 / 1130 \mathrm{BP}$ (K 3611), molluscs from the base of zone $E$ gave ages of 40,700 and $40,550 \pm 900 \mathrm{BP}$ (GrN-10023 and 10024) and plant material from the upper part of the same zone gave the age $47,300 \pm 1500 / 1200 \mathrm{BP}$ (GrN-9707). Zone $\mathrm{E}$ in Hirtshals is referred to the Moershoofd Interstadial complex (Lykke-Andersen, 1981 and 1982).

Consequently the Brorup Interstadial is not represented by zone IV in the Skærumhede II boring, as suggested by Bahnson et al., 1974, but is to be found deeper in the sequence. It is possible that a part of zone N2 in Skærumhede I belongs in the Brørup Interstadial, and the EemianWeichselian boundary could thus be represented by the zone N3-N2 boundary (figs. 2, 3 and 5).

A faunal succession corresponding to that described above from the Skærumhede sequence, is also found in other deep borings north and east of Skærumhede (Knudsen, in prep.). In a boring from Frederikshavn, however, a sequence with boreal deepwater faunas correlatable with zone N3 of Skærumhede I, is found at a much higher level. Its lower boundary is $100 \mathrm{~m}$ higher in Frederikshavn than in Skxrumhede, and the supposed Eemian sequence in Frederikshavn is less than $10 \mathrm{~m}$ thick (Knudsen, in prep.). In another deep boring located on the island of Anholt (fig. 1), a similar sequence with boreal deep water foraminifera, occurs at about the same level as in Frederikshavn, and the thickness is also here less than $10 \mathrm{~m}$ (Lykke-Andersen, in prep.). Such very pronounced differences in level as well as in the thickness of the Eemian deposits in this area suggest, that tectonic movements may have been active.
The geographical extension of the marine Skærumhede series is not known in detail. A deep water facies of Eemian age (zone N3) has not been found from other localities in Denmark (cf. Lykke-Andersen, in prep. and Knudsen, in prep.), but a similar fauna is described from the northern North Sea (Feyling-Hanssen, 1980). A shallower Eemian fauna is found at Fjösanger in SW Norway (Mangerud et al., 1981).

The Eemian of the Skærumhede I boring and the localities mentioned above represent deep water deposits in a basin, which occurred from the present Kattegatt, through Vendsyssel to the Skagerrak and the northern North Sea.

\section{Foraminiferal species}

Nørvang distinguished 47 different species of foraminifera in his material from the Skærumhede I boring. The relative frequencies of the 26 most common of these species are shown in the diagram, fig. 2, and 7 additional species are included in fig. 3 . These 33 species are listed alphabetically below together with their original references and a few comments:

\section{Ammonia batavus (Hofker)}

1951 Streblus batavus Hofker: Siboga Exped., Monogr. 4b (3), p. 492, 501, fig. 340.

\section{Buccella frigida (Cushman)}

1922 Pulvinulina frigida Cushman: Contr. to $\mathrm{Ca}$ nadian Biology 1921, p. 12 (144).

\section{Bulimina elongata d'Orbigny}

1826 Bulimina elongata d'Orbigny: Ann. Sci. nat. Paris, ser. 1 (7), p. 269 , no. 9.

Our analysis of Norvangs material suggests that he may have referred some specimens of Bulimina gibba Fornasini to B. elongata.

\section{Bulimina marginata d'Orbigny}

1826 Bulimina marginata d'Orbigny: Ann. Sci. nat. Paris, ser. 1 (7), p. 269 , pl. 12, figs. 10-12.

Fig. 5. Correlation of foraminiferal zones in Skærumhede I, Skærumhede II and Hirtshals, and their ecological interpretations. 
Cassidulina laevigata d'Orbigny

1826 Cassidulina laevigata d'Orbigny: Ann. Sci. nat. Paris, ser. 1 (7), p. 282, pl. 15, figs. 4, 5.

Cassidulina reniforme Nørvang

1945 Cassidulina crassa d'Orbigny var. reniforme Nørvang: The zoology of Iceland, Foram. Munksgaard (Copenhagen and Reykjavik) 2 (2), p. 41 , text-figs. $6 \mathrm{c}-\mathrm{h}$.

Cibicides lobatulus (Walker and Jacob)

1798 Nautilus lobatulus Walker and Jacob, in Adams, G.: Essays on the Microscope. Kanmacher. Ed. 2, London, p. 642, pl. 14, fig. 36.

Elphidium albiumbilicatum (Weiss)

1954 Nonion pauciloculum Cushman, subsp. albiumbilicatum Weiss: U.S. Geol. Survey, Prof. Paper 254-G, p. 157, pl. 32, figs. 1, 2.

\section{Elphidium asklundi Brotzen}

1943 Elphidium asklundi Brotzen, in Hessland, I.: Bull. geol. Inst. Uppsala 31, p. 267, fig. 109-1.

Nørvang probably included the two species $E l$ phidium bartletti Cushman and Elphidiella arctica (Parker and Jones) in E. asklundi (fig. 2).

\section{Elphidium excavatum (Terquem)}

1875 Polystomella excavata Terquem: Essay sur le Classement des Animaux qui vivent sur la Plage et dans les environs de Dunkerque. Pt. 1, Paris, p. 25, pl. 2, fig. 2.

Most specimens of $E$. excavatum in the present foraminiferal material belong to the forma clavata Cushman, but forma selseyensis (Heron-Allen and Earland) also occurs (see Feyling-Hanssen, 1972).

\section{Elphidium gerthi van Voorthuysen}

1957 Elphidium gerthi van Voorthuysen: Med. geol. Sticht., N. ser. 11, p. 32, pl. 23, fig. 12.

Elphidium groenlandicum Cushman

1933 Elphidium groenlandicum Cushman: Smithsonian misc. Coll. 89 (9), p. 4, pl. 1, fig. 10.

Elphidium macellum (Fichtel and Moll)

1798 Nautilus macellus Fichtel and Moll: Tes- tacea Microscopica. Vienna (Second ed. 1803), p. 66 , var. B, pl. 10, figs. h-k.

Elphidium magellanicum Heron-Allen and Earland

1932 Elphidium magellanicum Heron-Allen and Earland: Discovery Rep., Cambridge, 4, p. 440, pl. 16, figs. 26-28.

Elphidium margaritaceum Cushman

1930 Elphidium advenum (Cushman), var. margaritaceum Cushman: U.S. Nat. Mus., Bull. 104 (7), p. 25, pl. 10, fig. 3 .

Globobulimina turgida (Bailey)

1851 Bulimina turgida Bailey: Smithsonian Contr. Know. 2 (3), p. 12, figs. 28-31.

Hyalinea balthica (Schroeter)

1783 Nautilus balthicus Schroeter: Einleitung in die Conchylienkenntniss nach Linné. Gebauer (Halle) 1, p. 20, pl. 1, fig. 2.

Islandiella helenae Feyling-Hanssen and Buzas

1976 Islandiella helenae Feyling-Hanssen and Buzas: Journ. of Foram. Res. 6 (2), p. 156, figs. 1-4.

Nørvang grouped the two species $I$. helenae and $I$. norcrossi together. Therefore they can not be separated in the diagram, fig. 2.

Islandiella islandica (Nørvang)

1945 Cassidulina islandica Nørvang: The zoology of Iceland, Foram. Munksgaard (Copenhagen and Reykjavik) 2 (2), p. 42, fig. 7.

Islandiella norcrossi (Cushman)

1933 Cassidulina norcrossi Cushman: Smithsonian misc. Coll. 89 (9), p. 7, pl. 2, fig. 7.

See comments for 1 . helenae.

Nonion barleeanum (Williamson)

1858 Nonionina barleeanum Williamson: On the Recent Foram. of Great Britain. Roy. Soc. Publs., p. 32, pl. 3, figs. 68, 69.

Nonion depressula (Walker and Jakob)

1798 Nautilus depressulus Walker and Jacob, in 
Adams, G.: Essays on the Microscope. Kanmacher. Ed. 2, London, p. 641, fig. 33.

Nonion labradoricum (Dawson)

1960 Nonionina labradorica Dawson: Canadian Nat. 5, p. 191, fig. 4 .

\section{Nonion orbiculare (Brady)}

1881 Nonionina orbicularis Brady: Ann. Mag. Nat. Hist. London ser. 5 (8), 45, p. 415.

\section{Planorbulina distoma Terquem}

1876 Planorbulina distoma Terquem: Essay sur les Classement des Animaux qui vivent sur la Plage et dans les environs de Dunkerque. Pt. 2, Paris, p. 73. (Deuxieme Fascicule, Mém. Soc. Dunkerq. Encour. Sci., 20, 1877, p. 164, pl. 8, fig. 11).

\section{Planulina ariminensis d'Orbigny}

1826 Planulina ariminensis d'Orbigny: Ann. Sci. nat. Paris ser. 1 (7), p. 280, pl. 14, figs. 1-3.

\section{Pyrgo williamsoni (Silvestri)}

1923 Biloculina williamsoni Silvestri: Accad. Pont. Romana Nuovi Lincei, Atli 76, p. 73.

\section{Quinqueloculina padana Perconig}

1954 Quinqueloculina padana Perconig: Contr. Sci. Geol. Rome 3, p. 96, figs. 1-4.

$Q$. padana occurs only in zone N3 of the Skærumhede I boring. It was described by Nørvang as a new species "Miliolinella interglacialis" in his manuscript from 1940. His original drawings are shown in fig. 6. The chamber arrangement is quinqueloculine, but Nørvangs figures show a broad apertual flap, and not a bifid tooth as in the genus Quinqueloculina d'Orbigny, 1826. In a part of his manuscript Nørvang in fact suggested a new genus Quinqueloculinella should be erected for species with quinqueloculine chamber arrangement and an apertural flap. His description was, however, not published, and such a genus was later described with the name Scutoloris by Loeblich and Tappan (1953). We decided to refer the present species to Quinqueloculina and not to Scutoloris, because there is often a tendency towards a narrower flap, which in some cases is slightly bifid.
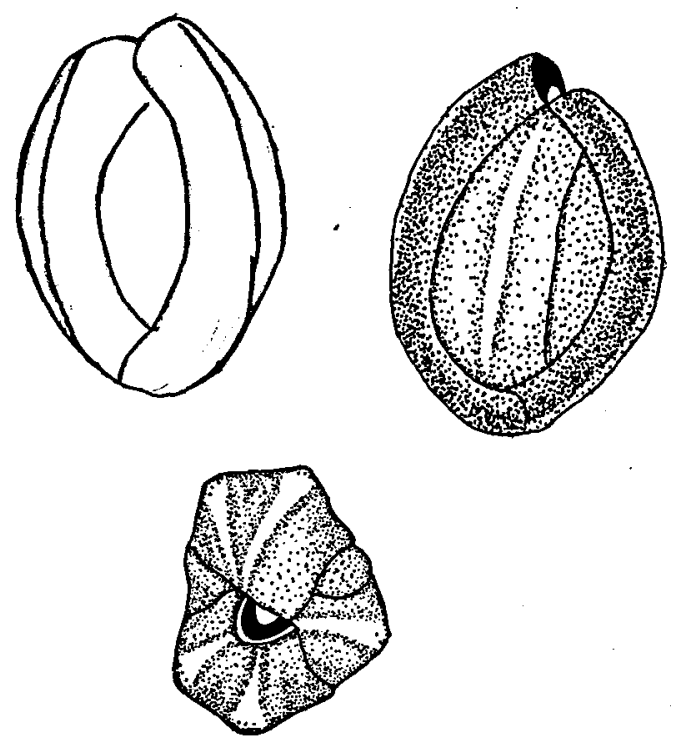

Fig. 6. Quinqueloculina padana Perconig. Axel Nørvang's original drawings.

A short description of Quinqueloculina padana was first given by Enrico Perconig in 1952 at a congress in Taormina, Sicily (Perconig, 1952, p. 137, figures and a full description published in 1954). He has kindly donated to us specimens from the Pliocene (Calabrian) of Valle del Tenna, Foglio Ferma, Italy, which confirm our reference of Nørvangs material to this species.

In 1954 Giunta described the species Quinqueloculina pentagona from the recent fauna of the Mediterranean (75 to $125 \mathrm{~m}$ water depth). According to the description and figures this species is undoubtedly synonumous with $Q$. padana.

As Nørvangs species description was never published, the species name padana Perconig, 1954 has priority and is used here. This name is also generally used in literature about the Pliocene, Pleistocene and Recent deposits in the Mediterranean area.

\section{Quinqueloculina seminulum (Linné)}

1758 Serpula seminulum Linné: Systema naturae. Ed. 10. Lipsiae 1, p. 786, pl. 2, fig. 1.

\section{Sigmoilina schlumbergeri Silvestri}

1904 Sigmoilina schlumbergeri Silvestri: Accad. Pont. Nuovi Lincei, Mem. 22, p. 267. 
Stainforthia loeblichi (Feyling-Hanssen)

1954 Virgulina loeblichi Feyling-Hanssen: Norsk geol. Tidsskr. 33, p. 191, pl. 1, figs. 14-18, textfig. 3.

\section{Triloculina trigonula (Lamarck)}

1804 Miliolites (trigonula) Lamarck: Ann. Nat. Hist. Mus. Paris 5, p. 351, no. 3, pl. 17, fig. 4 (no. 9, 1807).

\section{Uvigerina peregrina Cushman}

1923 Uvigerina peregrina Cushman: U.S. natl. Mus., Bull. 104 (4), p. 166, pl. 42, figs. 7-10.

Acknowledgments. We are grateful to the Geological Survey of Denmark for placing samples, foraminiferal collections, index cards, a rough draft of a manuscript and a range chart, left by the late Axel Norvang, at our disposal. In that connection we owe special thanks to Arne Buch for arranging and providing most of this material for us and to Peter Konradi for assistance with additional faunal analyses, and thanks also to Hans Jørgen Hansen for kindly helping us during our work with Axel Norvangs material.

We want to thank Rolf W. Feyling-Hanssen, Department of Micropaleontology, University of Aarhus for valuable discussions and for critically reading the manuscript, Jette Gissel Nielsen for making the drawings, and Lissi Østerhaab Mogensen for preparing the manuscript, and we are grateful to David N. Penney, University of Dublin, Trinity College, Dublin, Ireland for correcting the English of our manuscript.

\section{Dansk sammendrag}

Der er foretaget en foraminifer-stratigrafisk sammenstilling af den marine lagserie i Skærumhede I boringen fra 1905 baseret på en foraminifer-samling, enkelte prøver og et ufuldendt manuskript efterladt af afdøde Axel Nørvang. Resultaterne af denne er fremstillet i fig. 2 så nær Axel Nørvangs egne intentioner som muligt, og selve zonationen er taget direkte ud af hans optegnelser. Som supplement til disse undersøgelser er et udvalg af råprøver fra Skærumhede I boringen analyseret, og resultaterne er fremstillet $i$ fig. 3 .

Foraminifer-faunaerne i den marine Skærumhede Serie viser en faunistisk udvikling fra en nedre arktisk zone N4 til en boreal-boreolusitansk zone N3 med faunaer, som tyder på vanddybder på op til $60-100 \mathrm{~m}$ og temperaturer lidt højere end i dette område i dag. Derefter følger zone N2 med boreale lavtvandsfaunaer $i$ den nedre del og en overgang til boreoarktiske faunaer i den øvre del, og zone N1 med hovedsagelig arktiske faunaer.

Denne marine lagserie ved Skarumhede formodes at repræsentere Sen Saale, Eem, samt Tidlig og Mellem Weichsel. Den øvre del af den marine lagserie kan korreleres med foraminifer-zonerne, som er beskrevet i detaljer fra Skærumhede II boringen og fra Hirtshals Kystklint, mens foraminifer-faunaerne i den nedre del giver et udmærket supplement til denne stratigrafi.

Det nuværende kendskab til udbredelsen af det dybe Eem basin, som er repræsenteret ved zone N3 i Skærumhede I, tyder på, at dette har strakt sig fra området omkring Anholt over Vendsyssel til Skagerrak og den nordlige Nordsø.

\section{References}

Bahnson, H., Petersen, K. S., Konradi, P. B. and Knudsen, K L. 1974: Stratigraphy of Quaternary deposits in the Skærumhede II boring: lithology, molluscs and foraminifera. Danm. geol. Unders., Arbog 1973, 27-62.

Cita, M. B. and Chierici, M. A. 1962: Crociera talassografica adriatica 1955. V. Ricerche sui foraminiferi contenuti in 18 carote prelevate sul fondo del Mare Adriatico. Arch. Oceanogr. Limnol., 12 (3), 297-359.

Feyling-Hanssen, R. W. 1972: The foraminifer Elphidium excavatum (Terquem) and its variant forms. Micropaleontology, 18 (3), 337-354.

Feyling-Hanssen, R. W. 1980: Foraminiferal indication of Eemian interglacial in the northern North Sea. Bull. geol. Soc. Denmark, 29, 175-189.

Feyling-Hanssen, R. W., Jørgensen, J. A., Knudsen, K. L. and Lykke-Andersen, A.-L. 1971: Late Quaternary Foraminifera from Vendsyssel, Denmark and Sandnes, Norway. Bull. geol. Soc. Denmark, 21 (2-3), 67-317.

Feyling-Hanssen, R. W. and Knudsen, K. L. 1980: Foraminiferer og deres betydning i skandinavisk kvartær geologi. Dansk Natur Dansk Skole, Arsskrift 1979, 3-45.

Fält, L.-M. 1977: Gränsen Pleistocen/Holocen i marina sediment utanför svenska västkusten. Chalmers Tekn. Högskola och Göteborgs Univ., Geol. Inst., Publ. A 14, 1-39.

Giunta, M. 1954: Quinqueloculina pentagona n. sp. Riv. Ital. Pal. Strat., Milano, 60, no. 1, p. 33.

Hedberg, H. D. ed. 1976: International stratigraphic guide. A guide to stratigraphic classification, terminology and procedure. Wiley and Sons, New York, 1-200.

Höglund, H. 1947: Foraminifera in the Gullmar Fjord and the Skagerak. Zool. Bidr. från Uppsala, 26, 1-328.

Jessen, A., Milthers, V., Nordmann, V., Hartz, N. and Hesselbo, A. 1910: En boring gennem de kvartare Lag ved Skxrumhede. Danm. geol. Unders., II Rakke, 25, 1-175.

Kellogg, T. B. 1980: Paleoclimatology and paleo-oceanography of the Norwegian and Greenland seas: glacial-interglacial contrasts. Boreas, 9, 115-137.

Kellogg, T. B., Duplessy, J. L. and Shackleton, N. J. 1978: Planktonic foraminiferal and oxygen stratigraphy and paleoclimatology of Norwegian Sea deep-sea cores. Boreas, 7, 61-73.

Knudsen, K. L. 1976: Foraminifer faunas in Weichselian stadial and interstadial deposits of the Skærumhede boring, Jutland, Denmark. Maritime sediments, Spec. Publ. 1, B Paleoecology and Biostratigraphy, Halifax, 431-449.

Konradi, P. B. and Krudsen, K. L. 1974: Foraminifera in the Skarumhede II boring, 43-57. In: Bahnson, H., Petersen, K. S., Konradi, P. B. and Knudsen, K. L. 1974.

Lentini, F. 1968: Stratigrafia micropaleontologica dei terreni plio-pleistocenici di Sant' Arcangelo (Potenza). Atti Acc. Gioenia Sci. Nat. Catania, VI (19), Suppl. Sci. Geol., 255-344.

Loeblich, A. R. and Tappan, H. 1953: Studies of Arctic Foraminifera. Smithsonian Misc. Coll., 121 (7), 1-150.

Longinelli, A. 1956: Foraminiferi del Calabriano e del Piacenziano di Rosignano Marittimo e della Val di Cecina. $\mathrm{Pa}$ leont. Italica, 49, 99-214.

Lykke-Andersen, A.-L. 1971: Foraminifera from the Older Yoldia Clay in Hirtshals, 159-184. In: Feyling-Hanssen, R. W., Jørgensen, J. A., Knudsen, K. L. and Lykke-Andersen, A.-L. Bull. geol. Soc. Denmark, 21 (2-3), 67-317. 
Lykke-Andersen, A.-L. 1981: En ny C-14 datering fra Ældre Yoldia Ler i Hirtshals Kystklint. Dansk geol. Foren. Arsskrift for $1980,1-5$.

Lykke-Andersen, A.-L. 1982: Nogle nye C-14 dateringer fra Eldre Yoldia Ler i Hirtshals Kystklint. Dansk geol. Foren. Arsskrift for 1981.

Mangerud, J., Sønstegaard, E., Sejrup, H.-P. and Haldorsen, S. 1981: A continuous Eemian-Early Weichselian sequence containing pollen and marine fossils at Fjosanger, western Norway. Boreas, 10, 137-208.

Nagy, J. and Ofstad, K. 1980: Quaternary foraminifera and sediments in the Norwegian Channel. Boreas, 9, 39-52.

Nørvang, A. 1945: Foraminiferer fra Skærumhedeboringen. Meddr. dansk geol. Foren., 10, 645.
Perconig, E. 1952: La stratigrafia del sondaggio profondo n. 29 di Cortemaggiore. Atti del VII Convegno Nazionale del Metano e del Petrolio, Ires, Palermo.

Perconig, E. 1954: Note paleontologiche sulla zona costiera di Agrigento (Sicilia). Contr. Sci. Geol., Rome, 3, 91-98.

Risdal, D. 1964: Foraminiferfaunaenes relasjon til dybdeforholdene i Oslofjorden, med en diskusjon av de senkvartære foraminifersoner. Norges geol. Unders., 226, 1-142.

Sejrup, H.-P., Holtedahl, H., Norvik, O. and Miljeteig, I. 1980: Bethonic foraminifera as indicators of the paleoposition of the Subarctic Convergence in the Norwegian-Greenland Sea. Boreas, 9, 203-207. 